\title{
Chelidonium majus L. (Papaveraceae) morphology, anatomy and traditional medicinal uses in Turkey
}

\author{
Golshan Zare (1), Neziha Yağmur Diker (1), Zekiye Ceren Arıtuluk (1), İfet İrem Tatlı Çankaya (1) \\ Hacettepe University, Faculty of Pharmacy, Department of Pharmaceutical Botany, Ankara, Turkey
}

ORCID IDs of the authors: G.Z. 0000-0002-5972-5191; N.Y.D. 0000-0002-3285-8162; Z.C.A. 0000-0003-3986-4909;

i.i.T.C. 0000-0001-8531-9130

Cite this article as: Zare, G., Diker, N. Y., Arituluk, Z. C., \& Tatli Cankaya, I. I. (2021). Chelidonium majus L. (Papaveraceae) morphology, anatomy and traditional medicinal uses in Turkey. Istanbul Journal of Pharmacy, 51 (1), 123-132.

\begin{abstract}
Background and Aims: Chelidonium majus is known as "kırlangıç otu" in Turkey and the different plant parts, especially the latex and aerial parts have been used as folk medicines for different purposes such as digestion, hemorrhoids, jaundice, liver, eye, and skin diseases. Despite the traditional uses of Chelidonium, there have been no detailed anatomical studies related to this species.

Methods: The description and distribution map of $C$. majus was expended according to herbarium materials and an anatomical study was made using fresh materials. The information related to traditional uses and local names of this species was evaluated from ethnobotanical literature in Turkey. For anatomical studies freehand sections were prepared using razor blades and sections were double-stained with Astra blue and safranin.

Results: In the anatomical study, epidermal sections containing trichome and stomata characters were elucidated. The leaves are bifacial and hypostomatic. The stomata are anomocytic in the paradermal section. The cross-section of the stem showed multi-layered parenchymatous cells in the cortex and a single-layered endodermis with simple eglandular trichomes. The cross-section of the root showed that the epidermis was replaced with the periderm. Under the phloem, which had few layers, the xylem was composed of tracheary elements surrounded by sclerenchymatous cells.

Conclusion: Our results indicated that the morphological and anatomical characters alongside articulated laticifers and latex properties provide useful tools for the identification of this taxon from the other genera in the Papaveraceae family.

Keywords: Anatomy, Chelidonium majus, morphology, traditional uses, Turkey
\end{abstract}

\section{INTRODUCTION}

Papaveraceae Juss. is a medicinally important family comprising 23 genera and ca. 240 species found mainly in the Northern Hemisphere (Kadereit, 1993). All the family members are lactiferous with a well-developed duct system that produces a different kind of latex, from milky or watery white to yellow or red juice in all parts of the plant.

Chelidonium L. (greater celandine) from the Chelidonieae tribe is a world-wide distributed genus from temperate Eurasia to Northwest Africa and the Atlantic coasts of America (Cullen, 1965). Although this genus has been considered a monotypic genus for a long time, Krahulcová (1982) divided it into two separate species according to their different chromosome numbers and distribution areas: Chelidonium majus L. $(2 \mathrm{n}=12)$ distributed in Europe, Siberia and China and C. asiaticum (H. Hara) Krahulc $(2 n=10)$ distributed in East Asia and Japan. C. majus is one of the oldest medicinal plants, having been in use since ancient times, and Dioscorides and Pliny describe its uses to treat different diseases (Zielinska et al., 2018). 
Chelidonium, also known as greater celandine or devil's milk, has been used in various complementary and alternative medicine (CAM) systems including homeopathy and Traditional Chinese Medicine (TCM) to treat various skin disorders such as papillae, warts, condylomas, as well as ulcers, cancer, oral infection, liver disorders, chronic bronchitis, asthma, and general pain (EMA, 2010; Aljuraisy Mahdi \& Al-Darraji, 2012; Maji \& Pratim, 2015; Hao, Gu \& Xiao, 2015; Nawrot et al., 2017).

The latex of this species has been used externally for the treatment of skin conditions such warts, calluses, wounds, herpes, and cons in Iran (Miraldi, Ferri \& Mostaghimi, 2001) and in European countries including Croatia (Prieroni et al., 2003;Varga, Solic, Dujakovic, Luczaj\& Grdisa, 2019), Georgia (Bussman et al. 2017), Portugal (Gaspar et al., 2002; Novais, Santos, Mendes \& Pinto-Gomes, 2004; Neves, Matos, Moutinho, Queiroz \& Gomes, 2009), Slovenia (Lumpert \& Kreft, 2017), Albania (Pieroni, Dibra, Grishaj, Grishaj, Maçai, 2015), Romania (Papp, Birkas-Frendl, Farkas \& Pieroni, 2013), Italy (Leporatti \& Ivancheva, 2003; Bellia \& Pieroni, 2015; Guarrera, Forti \& Marignoli, 2005; Dei Cas et al., 2015; Menale et al., 2006; Passalacqua, Guarrera \& De Fine, 2007; Cornara, La Rocca, Terrizzano, Dente, F. \& Mariotti , 2014; Fortini, Marzio, Guarrera \& Iorizzi, 2016), Bosnia and Herzegovina (Redzic, 2007; Saric-Kundalic, Dobes, Klatte-Asselmeyer \& Saukel, 2010; 2011; Savic Macukanovic-Jocic \& Jaric, 2019), Kosovo (Mustafa et al. 2012), Spain (Blanco, Macia \& Morales, 1999; Gonzalez-Hernandez Romero, Rodriguez-Guitian \& Rigueiro, 2004; Benitez, Gonzalez-Tejero \& Molero-Mesa, 2010; Calvo, Akerreta \& Cavero, 2011; Rigat et al., 2015;), and Montenegro (Menkovic et al., 2011) (Figure 1). However, the leaves, flowers or aerial parts of C. majus are used internally in liver and gallbladder complaints in several countries (Ivancheva \& Statcheva, 2000; Leporatti \& Ivancheva, 2003; Pieroni, Dibra, Grishaj, Grishaj \& Maçai, 2005; Jaric et al., 2007; Menkovic et al., 2011; Savikin et al. 2013; Jaric et al., 2015). Besides these, it is used for the treatment of bronchitis, lithontriptic, stomach ulcers in Kosovo (Mustafa et al., 2012), for lung cancer in Bosnia and Herzegovina (Redzic, 2007), for diarrhea, asthma, and gastric disorders in Iran (Miraldi, Ferri \& Mostaghimi, 2001), for cold, asthma, bronchitis, and pneumonia in Spain (Menendez-baceta et al. 2014), as abortifacient in Italy (Idolo, Motti \& Mazzoleni, 2009), against cancer, for hemorrhoids and blood cleansing in Ukraine, as well as for kidney problems in Romania (Soukand \& Pieroni, 2016) (Figure 1).

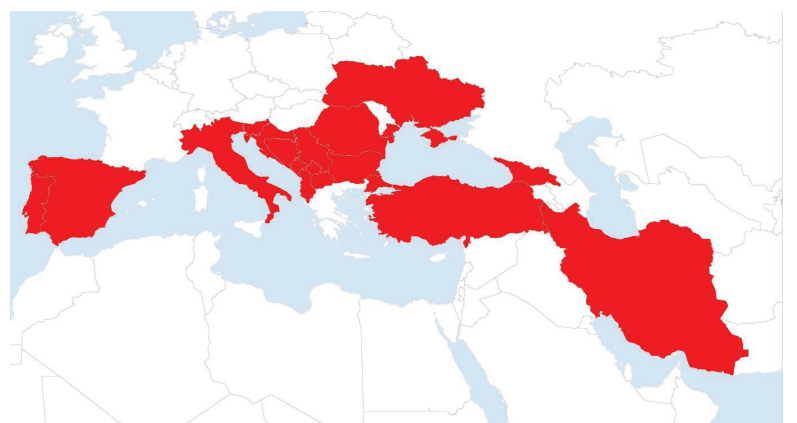

Figure 1. Distribution map of countries with traditional use of Chelidonium.
In Turkey, C. majus is called "kırlangıç otu" (Güner, Aslan, Ekim, Vural \& Babaç, 2012) and it has been used as a traditional medicinal plant for 26 different purposes in ten provinces mainly located in the Northwestern parts of Turkey.

The aerial parts, leaves and flowers of the plant are used both externally and internally, while the latex is used only externally for the treatment of skin diseases. Applying the latex directly to remove warts is the most common medicinal use of the plant (Uzun et al., 2004; Kültür, 2007; Ünsal, Vural, Sarıyar, Özbek \& Ötük 2010; Kızılarslan \& Özhatay, 2012; Akbulut \& Özkan, 2014; Sargın, Akçicek \& Selvi, 2013; Saraç, Ozkan \& Akbulut, 2013; Sargın, Selvi \& Lopez, 2015; Polat, Cakilcioglu, Kaltalioğlu, Ulusan \& Türkmen, 2015; Mumcu \& Korkmaz, 2018). The traditional medicinal uses of C. majus in Turkey are presented in Table 1.

The greater celandine herb has been approved by both the European Pharmacopoeia and Turkish Pharmacopoeia. In addition, it has also been included in Commission E monographs for its use in spastic discomfort of the bile ducts and gastrointestinal tract, gall bladder and skin diseases (EMA, 2010; WHO, 2010; Görsöz, 2018). Pharmacological studies indicated Chelidonium extracts have anti-viral (Zuo, 2008; Gilca, Gamana, Panaita, Stoian \& Atanasiu 2010), anti-microbial (Kokoska, 2002), anti-tumor, anti-inflammatory (Lee, 2007) and analgesic properties (Huang, 1999).

Chelidonium is a particularly well-known genus because of the presence of numerous therapeutically important alkaloids located in the different parts of the plant, especially in the latex. More than forty alkaloids including phenanthridine (3,4-benzylisoquinoline), protoberberine, protopine, quinolizidine, aporphine) have been isolated from Chelidonium (Kedzia, Łozykowska, \& Gryszczynska, 2013; Hao, Gu \& Xiao, 2015; Zielinska et al., 2018). Isoquinoline alkaloids are pharmacologically relevant substances of this taxon (Grosso et al., 2014; Zielinska et al., 2018).

According to the therapeutic potential and traditional uses of C. majus and its hepatotoxic effect in chronic administration (EMA, 2010; WHO, 2010; Pantano et al., 2017), it is important to conduct morphological and anatomical studies to provide reliable diagnostic characters for the identification of raw material and commercial samples to avoid any unwanted toxic harm.

Despite the medicinal uses of Chelidonium species, there has not been any detailed research on the anatomical and morphological properties of the genus in Turkey. In this study, we provide detailed anatomical properties of C. majus, expanded morphological information and a distribution map based on Turkish samples. In addition, the traditional uses of this plant in Turkey are discussed in detail.

\section{MATERIAL AND METHODS}

Fresh plant materials at the flowering period were collected from Ankara, Turkey in June 2019 by Golshan Zare (GZ1309). Voucher specimens were deposited in the Hacettepe University Faculty of Pharmacy Herbarium under the classification code HUEF20008. For morphological investigation, 44 speci- 
Table 1. Traditional medicinal uses of $C$. majus in Turkey.

\begin{tabular}{|c|c|c|c|c|c|c|}
\hline Province & Local name & Parts Used & Preparation & Administration* & Use & Literature \\
\hline Afyonkarahisar & Kırlangıç otu & Aerial parts & Infusion & Int. & $\begin{array}{l}\text { Digestion, hemor- } \\
\text { rhoids, jaundice, } \\
\text { liver, eye disease, } \\
\text { skin diseases }\end{array}$ & $\begin{array}{l}\text { Arı et al., } \\
2015\end{array}$ \\
\hline Bilecik & Kırlangıç otu & Latex & Raw & Ext. & Warts & $\begin{array}{c}\text { Unsal et al., } \\
2010\end{array}$ \\
\hline Giresun & Kına otu & $\begin{array}{l}\text { Flowers } \\
\text { Leaves }\end{array}$ & Decoction & Ext. & Warts & $\begin{array}{l}\text { Polat et al., } \\
2015\end{array}$ \\
\hline Izmit & Temre otu & $\begin{array}{l}\text { Aerial parts } \\
\text { Latex }\end{array}$ & $\begin{array}{l}\text { Infusion } \\
\text { Raw }\end{array}$ & $\begin{array}{l}\text { Int. } \\
\text { Ext. }\end{array}$ & $\begin{array}{c}\text { Diuretic } \\
\text { Wounds, eczema }\end{array}$ & $\begin{array}{c}\text { Kızılarslan } \\
\text { and Özha- } \\
\text { tay, } 2012\end{array}$ \\
\hline \multirow[t]{3}{*}{ Kırklareli } & \multirow{3}{*}{$\begin{array}{c}\text { Sarılik otu, } \\
\text { Sultan otu, } \\
\text { yara otu, } \\
\text { temra otu, } \\
\text { mayasıl otu }\end{array}$} & Herba & Decoction & $\begin{array}{l}\text { Ext. } \\
\text { Int. }\end{array}$ & Hepatitis & \multirow[t]{3}{*}{ Kültür, 2007} \\
\hline & & Latex & Raw & Ext. & $\begin{array}{l}\text { Inflamed wounds, } \\
\text { wounds, warts, } \\
\text { itching, hemo- } \\
\text { static }\end{array}$ & \\
\hline & & Leaves & Decoction & Ext. & $\begin{array}{l}\text { Rheumatism, } \\
\text { sciatica }\end{array}$ & \\
\hline \multirow[t]{3}{*}{ Manisa } & \multirow[t]{3}{*}{$\begin{array}{l}\text { Siğil otu, } \\
\text { Bostan otu }\end{array}$} & Aerial parts & Infusion & Int. & $\begin{array}{l}\text { Spasm, dyspepsia, } \\
\text { gastrointestinal } \\
\text { diseases }\end{array}$ & \multirow{2}{*}{$\begin{array}{l}\text { Sargın et } \\
\text { al., 2013; } \\
\text { Sargın et } \\
\text { al., } 2015\end{array}$} \\
\hline & & & Raw & Ext. & $\begin{array}{l}\text { Carminative, cos- } \\
\text { tiveness, warts, } \\
\text { corns }\end{array}$ & \\
\hline & & Leaves & Mash & Ext. & Warts & $\begin{array}{l}\text { Sargın et } \\
\text { al., 2013; }\end{array}$ \\
\hline Rize & $\begin{array}{l}\text { Mecmenuk } \\
\text { çayırı }\end{array}$ & Aerial parts & Raw & Ext. & $\begin{array}{l}\text { Eczema, warts, } \\
\text { acne }\end{array}$ & $\begin{array}{c}\text { Saraç et al., } \\
2013\end{array}$ \\
\hline Sakarya & --- & Aerial parts & Infusion & Int. & Eczema & $\begin{array}{c}\text { Uzun et al., } \\
2004\end{array}$ \\
\hline \multirow[t]{2}{*}{ Samsun } & Kırlangıç otu & Aerial parts & --- & Int. & $\begin{array}{l}\text { Diuretic, purga- } \\
\text { tive, caustic }\end{array}$ & \multirow{2}{*}{$\begin{array}{c}\text { Mumcu and, } \\
\text { Korkmaz, } \\
2018\end{array}$} \\
\hline & & Latex & --- & Ext. & Warts, ringworm & \\
\hline Trabzon & Temre & Latex & Raw & Ext. & Skin diseases & $\begin{array}{c}\text { Akbulut } \\
\text { and Ozkan, } \\
2014\end{array}$ \\
\hline
\end{tabular}

mens of C. majus from the Ankara University Faculty of Science Herbarium (ANK), Hacettepe University Faculty of Science Herbarium (HUB), Ankara University Faculty of Pharmacy Herbarium (AEF), Hacettepe University Faculty of Pharmacy Herbarium (HUEF) and Edinburgh (E) Virtual Herbarium were studied and Flora of Turkey and the East Aegean Islands (Cullen, 1965) were followed for terminology and description order. The distribution information related to herbarium samples, records of flora in Turkey and the East Aegean Islands and the collected fresh materials of $C$. majus were plotted on a map (Figure 2). Determination and measurement of microscopic characters were done by means of direct observation under Leica Stereo Microscopes (Model EZ4) and photographed.

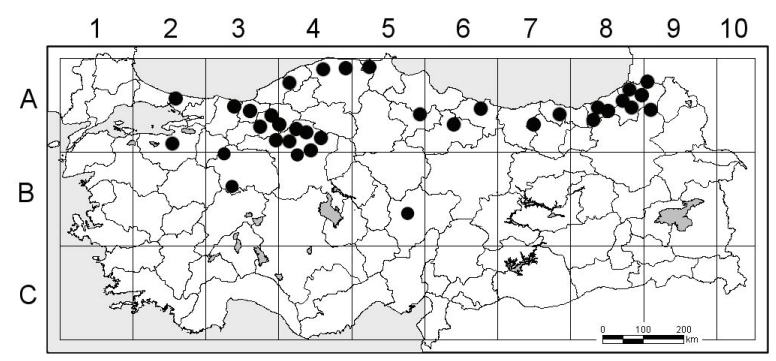

Figure 2. Distribution map of C. majus in Turkey.

Fresh specimens (GZ1309) were used for the anatomical investigations and cross-sections were prepared from leaves (at middle), stems (basal and top), pedicels and roots. Paradermal 
sections were also performed for leaves. Freehand sections were prepared using razor blades and sections were cleared with sodium hypochlorite and then stained by double stain with Astra blue and safranin. Slides were observed with a Leica CME light microscope and photographed.

\section{RESULTS AND DISCUSSION}

\section{Morphology}

Chelidonium majus L., Sp. PI. 505 (1753).

Kırlangıç otu (Güner, Aslan, Ekim, Vural \& Babaç, 2012).

Type: Described from Europe (Hb. Linn. 668/1).

Synonyms: C. laciniatum Mill., Gard. Dict., ed. 8. n. 2 (1768). C. majus var. grandiflorum DC., Syst. Nat. 2: 99 (1821). C. laciniatum var. fumariifolium DC., Syst. Nat. 2: 100 (1821). C. umbelliferum Stokes, Bot. Mat. Med. 3: 180 (1812).

Perennial herb, 30-70(-100) cm, branched at the base. Rhizome thick, fleshy, reddish-brown. Stem erect, branched with bright orange sap, sparsely pubescent, especially on the nodes, woody stock covered by persistent leaf. Basal leaves petiole 2-14 (18) cm, blade glaucous abaxially with conspicuous veins, green adaxially, obovate-oblong or broadly obovate, $8-20 \mathrm{~cm}$, abaxially sparsely pubescent especially on the veins, adaxially glabrous, bipinnatifid or pinnatisect, lobes 2-4 pairs, obovate-oblong, irregularly parted or lobed; lobe margin crenate. Cauline leaves alternate, petiole 5-18 mm; blade 2-12 (-15) x 1-8 cm, leaves pinnate with 5-7 broad leaflets, the terminal leaflet often 3 -fid, ovate to oblong. Inflorescence nearly umbellate with flowers (2) $-5-7$ (8). Pedicel tenuous, $2-8 \mathrm{~cm}$, pubescent when young, later glabrous. Flowers 2-2.5 cm across. Sepals 2, free, caducous, ovoid, 5-8 mm, glabrous or sparsely pubescent. Petals 4, yellow, obovate, $10 \times 8-15$ mm, entire. Stamens $8 \mathrm{~mm}$ numerous. Filaments yellow, anthers oblong. Style short, with 2 spreading stigma-lobes (Figure 3). Ovary
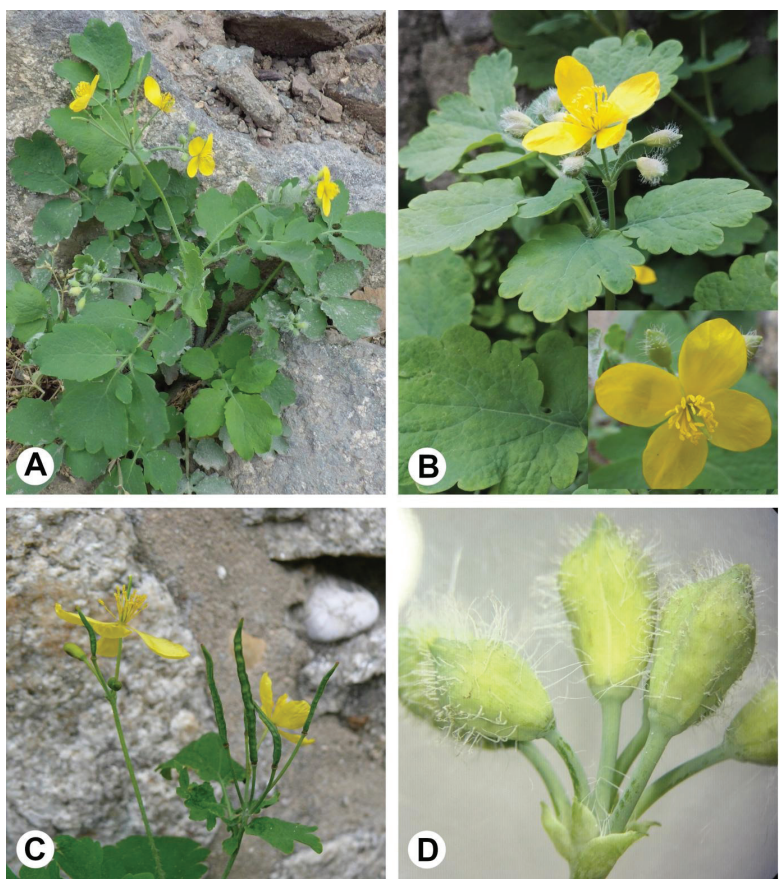

Figure 3. A, Habitus; B, flower and inflorescence; C, capsule fruit; D, flower buds with trichomes. linear, $1 \mathrm{~cm}$, glabrous. Fruit slender siliqua-like capsule (2) 30-60 x 2-4 mm, torulose, glabrous, monolocular, without a septum, basipetal, opening from below by 2 valves, many seed, pedicel the same as or usually shorter than fruit. Seeds 1-2 mm, dark brown or black, shiny in fresh material, reticulate patterned, with a white appendage, ovoid, alveolate (Figure 4).

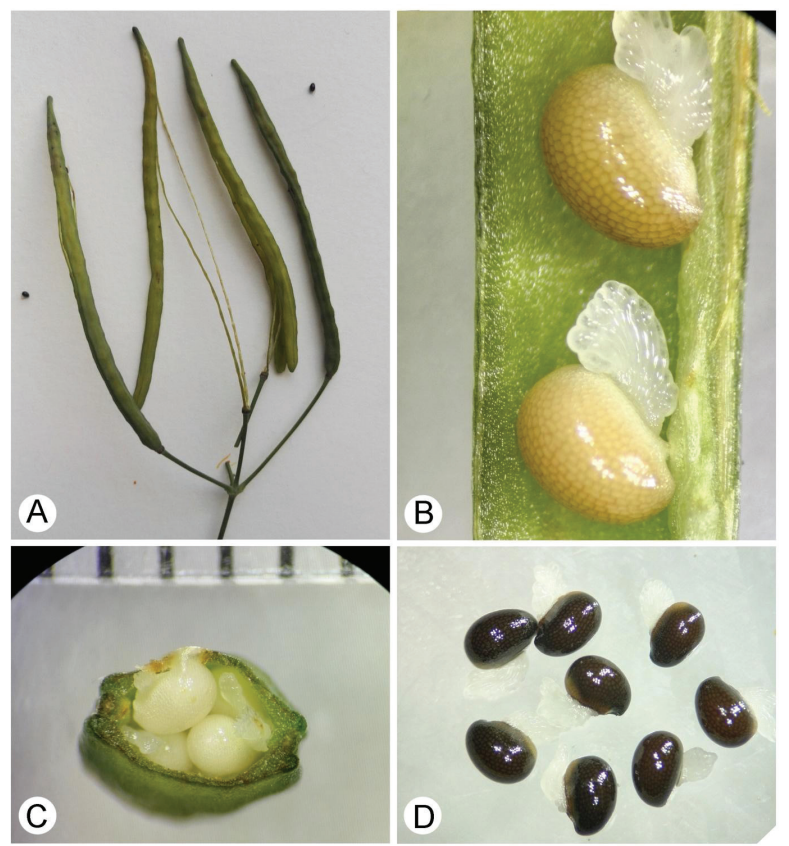

Figure 4. A, Fruit; B, fruit longitudinal sections; $C$, fruit Transverse sections; $D$, seed.

Flowering time: April-August.

Habitat: Shaded ground in woods and thickets, sea level-2000 $\mathrm{m}$.

Phytogeographic region: Euro-Siberian element.

World distribution: Widespread in Asia, North America and whole Europe, Northwest Africa; it grows in forests and open shrubby areas, shady, ruderal sites.

Turkey distribution: West and Black Sea regions (Figure 2).

Examined specimens: A2(E) Istanbul: Kestanesou, 22.06.1895 Aznavour (E!); Bursa: Uludağ to Soğukpınar, 500-1000 m, 16.05.1962, Dudley 34741(E!). A3 Bolu: Karadere to Yedigöl, 650 m, 18.06.1962, P.H.Davis \& Coode, 37688 (E!); Bolu to Abant lake, 800-900 m, 14.07.193, S. Fehmi (ANK!); Yedigöller National Park, 1000 m, 13.06.1977, R. Ilarslan 102 (ANK!); Düzce: Aşağıkaraköy, Çilimli, 2000 m, 16.05.2009, A. Mine Gençler Özkan, I. Gürbüz, G. Akaydın, E. Miser 26472 (AEF!); Akçakoca, Küpler village, 350-370 m, 22.07.2002, A. Doğru Koca 1864 (HUB!); Ankara: between Beypazarı and Kıbrısak, around Yiğenler village, 1050-1300 m 01.06.2001, Ali A. Dönmez 8953 (HUB!); Ankara: Çankaya, Bülbülderesi, by the road, 945 m, 20.06.2019, G. Zare 1309 (HUEF!); A4 Zonguldak: Amasra, 14.04.1985, Venter (HUB!); Ankara: Beypazarı, Dereli, 1300 m, 02.07.1978, Y. Akman 75 (ANK!); Ankara: Çubuk, Karagöl, around the lake, 1500 m, 23.05.1973, 
S. Erik 423 (HUB!); Kızılcahamam, around Güven, 1200 m, 13.06.1992, M. Koyuncu 9792 (AEF!); ibid., 22.07.2002, H. Duman 2291 (AEF!); Seyhamamı, stone pit, 1000 m, 27.07.1975, B. Kasaplıgil, S. Başaran (AEF!); Maden suyu, 1000 m, 17.07.1977, K. Karamanoğlu, M. Coşkun 14513 (AEF!); Kızılcahamam, Çamları village, 02.07.1948, K. Karamanoğlu 522 (ANK!); Kastamonu: Azdavay to Cide, 800 m, 31.07.1962, P.H.Davis 38690 (E!); between Cide-Kızılca, 900 m, 12.06.1979, O. Ketenoğlu 1387 (ANK!); İnebolu, 18.04.1932, W. Katte (ANK!). A5 Kastamonu: Yağalar village, 1500 m, 12.06.1975, M. Kılıç 3324 (ANK!); Ayancık, Çangal, 1100 m, 11.08.1945, Bakı Kasaplıgil (ANK!); Amasya, 30.06.1893, A. Manissadjian 754 (E!). A6 Tokat: Artova, Aktaş, Çal Tepe, ca. 13001400 m, 16.07.19, R. Ilarslan 588 (ANK!). A7 Giresun: Gengene village, 700 m, 24.06.1977, Y. Akman 702 (ANK!); Gümüşhane: Harava village, 1100 m, 17.08.1983, Ş. Yıldırımlı 5736 (HUB!). A8 Trabzon: Sürmene, around Köprübaşı, 700 m, 29.04.1982, A. Güner 4292, B. Yıldız (ANK! AEF!); Uzungöl castel, 28.07.1994, N. Tanker, M. Koyuncu, M. Yıldız, S. Kuruas (AEF!); Rize: Çamlıhemşin, near Zilkale, c. 700 m, 16.08.1980, A. Güner 3061 (HUB!); Salarha, Kömürcüler village, 200 m, 21.04.1985, A. Güner 6282, M. Bilgin (HUB!); 2. km from Güneyce to Ikizdere, 320 m, 26.03.1983, A. Güner 4610, B. Yıldız, M. Bilgin (HUB!); Artvin: Arhavi, around Ortacalar, 750 m, 21.04.1984, M. Koyuncu 6782, T. Ekim, A. Güner, M. Bilgin (AEF!); Dikyamaç village, 750 m, 22.04.1997, M. Coşkun 19870 (AEF!); Alaca (Tiryal) southeast slope, 163 m, 14.06.1978, A. Düzenli 895 (ANK!); Artvin: Dikyamaç village, 05.06.1993, M. Coşkun 184 (AEF!); Borçka, 50 m, 18.05.1985, ş. Yıldırımlı 7876 (HUB!); Çoruh, 1100 m, 28.04.1960, Stainton 8301(E!). A9 Artvin: Çoruh, Ardanuç to Kordevan mountain, 1450 m, 27.06.1957, D. 30140 (E!); Kars: Posof, 1600-1750 m, 29.06.1986, N. Demirkuş 3658 (HUB!). B3 Afyonkarahisar: Şuhut, Koçyatağı village, 28.05.2003, 1200 m, Ahmet Sezgin 03048 (HUEF!); Eskişehir: Türkmen mountain, 1400 m, 07.06.1985, T. Ekim 2550 (ANK!). B5 Kayseri: Hisarak, 14.06.1944, H. Bağda (ANK!).

\section{Anatomy}

The anatomical structures of the specimen were determined by examination of the root, stem, pedicel and leaf cross-sections. Additionally, the stomatal index of the species is presented in Figures 5-8.

Trichome: The surfaces of all parts of this species contain simple, uniseriate (4-6 cell) and eglandular trichomes whose density show variation in different parts of individuals and among the population (Figures $5 \mathrm{~A}-\mathrm{C}$ ). On the leaf surface, trichomes are dorsiventral and density is higher on the veins and nods.

Leaves: Cross-sections of the leaf blades in both surfaces contain epidermal cells with sinuous anticlinal walls covered by a thin layer of cuticula. The superior epidermis of the leaf consists of 4-6 angled, rectangular, anisodiametric cell layers and stomata are absent. Mature epidermis cell size is $79.16 \pm 16.35$ $\times 26.66 \pm 5.77 \mu \mathrm{m}$. Leaves are hypostomatous and stomata are confined to the lower surface (abaxial). Stomata type is ranunculaceous (anomocytic) and guard cells are surrounded with 4-6 cells which are not distinct from the remaining cells in the mature epidermis (Figure 5 D-E). Upper epidermis have slightly larger cells than lower epidermis. These cells are significantly wavy in anticlinal walls, with $21 \pm 4.0 \mu \mathrm{m}$ width in narrow the

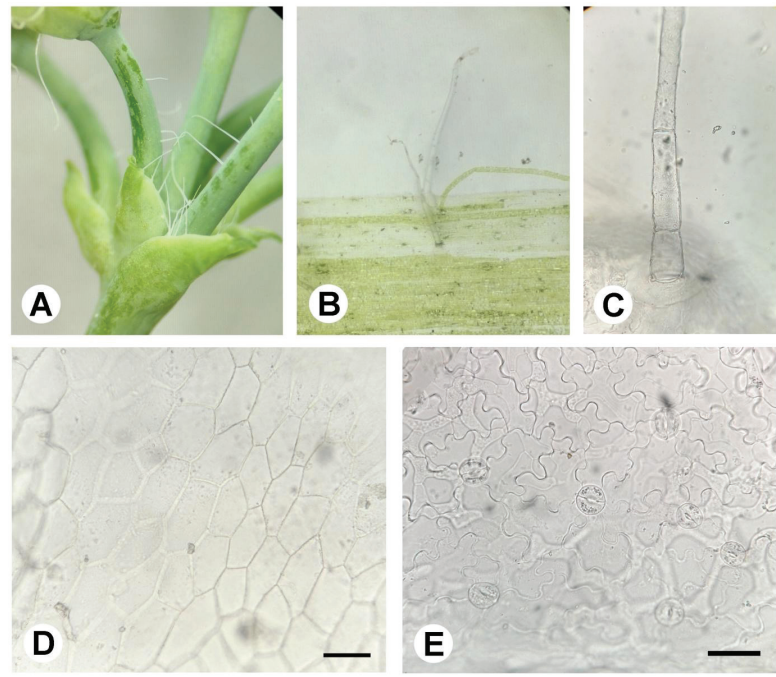

Figure 5. Transverse sections of the epidermis, $A-C$, uniseriate hairs; $D_{\text {, }}$ adaxial epidermis; $E$, abaxial epidermis with ranunculaceous type stomata. Scale bars: (D, E) $50 \mu$.

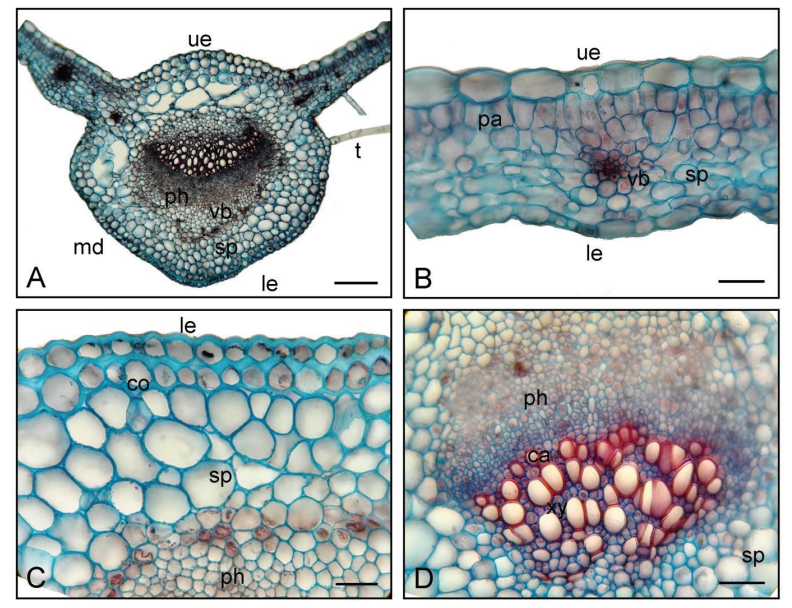

Figure 6. Transverse sections of Leaf. A, C, and D, midrib; B, blade; ca, cambium; ue, upper epidermis; le, lower epidermis; pa, palisade cell; sp, spongy parenchyma cell; ph, phloem; t, trichome; $x y, x y l e m$. Scale bars: (A), $200 \mu,(B, C, D) 50 \mu$.
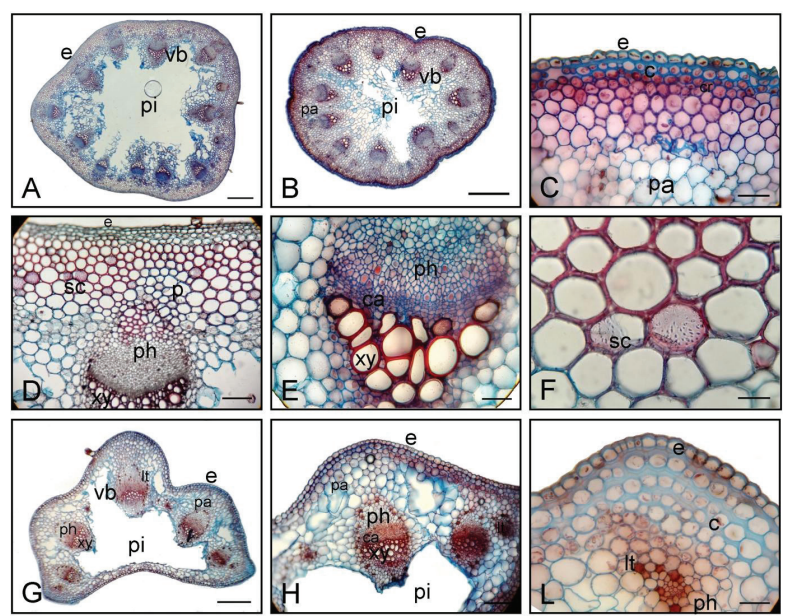

Figure 7. Transverse sections of stem and pedicel. A-F Stem; G-L, pedicel. ca, cambium; co, cortex; ue, upper epidermis; le, lower epidermis; pa, palisade cell; sp, spongy parenchyma cell; ph, phloem; pi, pith region; vb, vascular bundle; sc, secretery cell; $x y, x y l e m$. Scale bars: $(A, B, G) 500 \mu,(D, H), 200 \mu,(C, E, F, L) 50 \mu$. 


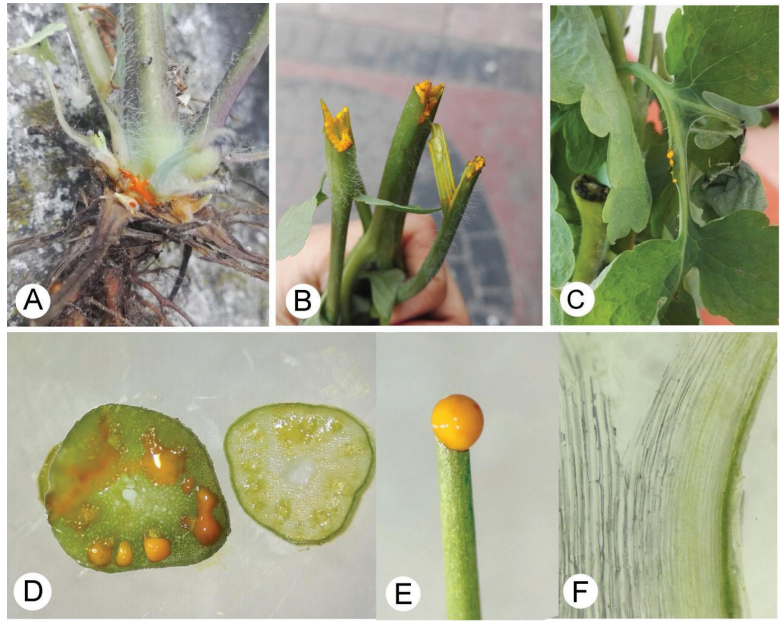

Figure 8. A-C, Orange latex in root, stem and leaves of the Chelidonium; $D$ cross section of stem; E and F, Transverse and longitudinal section of stem and articulated laticiferous tubes.

part, $73.00 \pm 9.2 \mu \mathrm{m}$ width in the large part of the cells and $42.36 \pm 3.98 \mu \mathrm{m}$ length. The inferior epidermis consists of numerous stomata whose rounded shape and stomata index is $19.66 \pm 1.61\left(\mathrm{~mm}^{2}\right)$. Stomata size is $21.5 \pm 2.1 . \times 21.13 \pm 2.0 \mu \mathrm{m}$. In leaf cross-section slides indicated leaves have bifacial (dorsiventral) structure and the palisade layer is restricted to the upper side (Adaxial). Leaf thickness is between 180-200 $\mu \mathrm{m}$ and the mesophyll structure generally includes one or several layers of palisade parenchyma cells under the upper epidermis and thin-walled spongy parenchyma cells with wide intercellular spaces. However, the transverse region is sometimes not distinctly differentiated into palisade and spongy regions (Figures 6). The leaf main vein thickness is 800-1100 $\mu \mathrm{m}$, contains 1-3 layers of collenchyma under the epidermis and 3-5 layers of thin-walled parenchyma cells with different sizes between the collenchyma layer and the arc-shaped vascular bundles. In this area, a few calcium oxalate crystals were seen in the cells. Veins contain numerous collateral vascular bundles, with the xylem located on the upper side and phloem located on the lower side, and in main vein latex cells found in the vascular region (Figure 6).

Stem: The stem transverse section in the young part is circular and in the old part tends to show a pentagonal shape with rounded corners. The outer part is covered with a single layer of epidermal cells with a thin cuticula. Multicellular simple trichomes are seen on the epidermis. Immediately under the epidermis single or multi-layered collenchymatous cells were detected. The cortex consists of multi-layered parenchymatous cells that have various shapes and sizes. Vascular bundles are collateral and 12-14 bundles are arranged in a single ring with concentric zones. The xylems generally tend to be $\mathrm{V}$-shaped. In vascular bundles, 2-6 cambium layers between phloem and xylem are distinguishable. The xylem part is larger than the phloem part. The pith consists of parenchymatous cells that are large and polygonal in shape. This tissue is torn in the lower part of the stem and these tears form a pith cavity (Figure 7AB). Latex is generally present throughout all parts of the plant and is found in articulated laticiferous tubes. Laticiferous tubes are placed in vascular bundles close to the phloem. In some of the cross-section slides, sieve plates related to the transverse or lateral walls of these tube cells were found (Figures 8). Calcium oxalate crystals occur in the parenchymatous cells.

Petiole: The petiole cross-section is triangular and its anatomical structure is similar to the stem structure. It contains a single layer of epidermis, one to several layers of collenchyma in the corners, and commonly exhibits an arc of vascular bundles without sclerenchyma. Also, there are articulated laticiferous latex tubes and cells and crystals of calcium oxalate in the cortex cells (Figures $7 \mathrm{G}-\mathrm{L}$ ).

Root: The root structure indicates that this plant is annual. The periderm is generally scratched from the cortex and the cortex is multi-layered with 20-35 layers. Endodermis cannot be distinguished and borders are not clear. The primary structure in the central vascular bundle is diarch and xylem places under phloem (Figures 9).

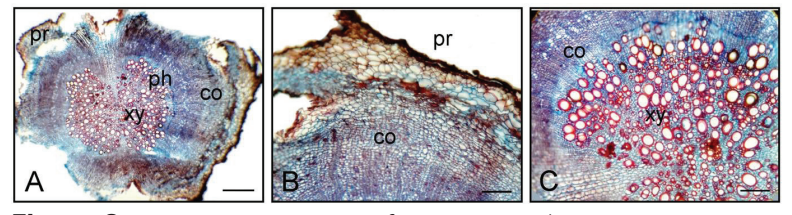

Figure 9. Transverse sections of root. a, cambium; co, cortex; pr, periderm; ph, phloem; pi, pith region; vb, vascular bundle; $x y, x y l e m$. Scale bars: (A) $500 \mu,(B, C), 200 \mu$.

\section{DISCUSSION}

In this study, we investigated the distribution area, morphological and anatomical properties of C. majus as one of the traditional medicinal plants in Turkey. There are lots of studies on the phytochemical and therapeutic perspective of the genus Chelidonium (Kedzia Łozykowska \& Gryszczynska, 2013; Grosso et al. 2014; Zielinska et al. 2018) but the distribution area, morphological and anatomical features of this species have not been taken into consideration, especially in Turkey.

The distribution area of Chelidonium in Flora of Turkey (Cullen 1965) is restricted to the Black Sea region and this taxon is known as the Euro-Siberian element. Our findings indicated this species grows abundantly in the transition area from Euro-Siberian to Irano-Turanian phytogeographic area. There are two records from Afyonkarahisar and Kayseri that are far from the natural distribution area of this species (Figure 2). This can be caused by anthropogenic impact or seeds being carried by animals. The habitats of this plant are forests and shady rural areas. We also found lots of individual plants in parks and roadsides in the cities.

Our results on morphological features are in agreement with the description of the taxon in the Flora of Turkey (Cullen, 1965). We also expended morphological characters according to 44 examined samples from fresh material and herbarium mentioned specimens. The shape of the leaves, umbellate inflorescence, small, yellow flowers, basipetal dehiscence capsule shaped fruits with deciduous valves and arillate seeds can be used to differentiate this species from other members of the family. 
Although latex secretion in many unrelated families decreases its diagnostic value, whatever the chemical nature of its contents, it can be helpful in the taxonomy of taxa (Metcalfe \& Chalk, 1957). In the Papaveraceae family, the presence of latex is a predominant character among members that shows the variation in colour and chemical component (Metcalfe \& Chalk, 1957; Kadereit, 1993). The shiny orange latex found in all organs of the plant is peculiar to C. majus and is placed in articulated non anastomosing laticifers (Figure 8). Also, in agreement with Kadereit (1993), this tube significantly associated with the phloem of the vascular bundle and these structures can easily be distinguished even in broken or powdered herbal drugs (Pallag, Pasca, Taichiș, Honiges \& Moisa, 2015; İşcan, Köse \& Demirci, 2019). Kadereit (1993) indicated latex tends to disappear from the older parts of the plant; however, we found it in the old parts but the amount was low.

While the trichome types provided an important diagnostic character among the species of Papaveraceae family, the results indicated that uniseriate trichomes are diagnostic for the whole tribe Chelidonieae. In addition, considering the diagnostic value of epidermal cell shape, the presence of stomata just in the adaxial side of leaves, in contrast with other genera such as Papaver and Roemeria (Metcalfe \& Chalk, 1957) and the stomata index can provide confirmatory evidence in the identification of this taxon.

These results can help to facilitate the identification of material for use by people, detecting contamination of this taxon with other herbal drugs and providing identified raw material for scientific research in the medicinal field.

C. majus is one of the oldest medicinal species, having been in use since ancient times. This plant was cited by Dioscorides to treat jaundice and dermatologic disorders and Pliny the Elder for the preparation of eye lotion (Jones, 1966; Dioscorides, Osbaldeston \& Wood, 2000). C. majus has been extensively used to treateye diseases, ulcers and skin disorders as well as against colic and jaundice in Europe (Mayer, Uehleke \& Saum, 2003). In Turkey, especially in the Black Sea region, a distribution area of Chelidonium, the different parts of this plant, commonly latex and the aerial parts of the plant have been used as folk medicines for the treatment of different diseases (Table 2). The latex is externally as hemostatic and for the treatment of skin diseases such as wounds, eczema, warts, ringworm, and itching (Kültür, 2007; Ünsal Vural, Sarıyar, Özbek \& Ötük, 2010; Kızılarslan \& Özhatay, 2012; Akbulut \& Özkan, 2014; Mumcu \& Korkmaz, 2018). The infusions of aerial parts are used internally to treat hepatitis (Kültür, 2007), hemorrhoids, jaundice, liver, eye and skin diseases (Arı et al. 2015). In addition, it is used for gallbladder, (Mumcu \& Korkmaz, 2018), and gastrointestinal diseases such as digestion, spasm, dyspepsia (Sargın, Akçicek \& Selvi, 2013; Sargın, Selvi \& Lopez, 2015; Mumcu \& Korkmaz, 2018) and used as purgative and diuretic (Kızlarslan \& Özhatay, 2012; Mumcu \& Korkmaz, 2018). It is also used externally to treat warts, corns, acne (Sargın, Akçicek \& Selvi, 2013; Saraç, Ozkan \& Akbulut, 2013; Sargın, Selvi \& Lopez, 2015), eczema (Uzun et al., 2004; Saraç, Ozkan \& Akbulut, 2013; Polat, Cakilcioglu, Kaltalioğlu, Ulusan \& Türkmen, 2015), and rheumatism (Kültür, 2007).
In traditional medicine different parts of the plant are used for several therapeutic purposes. Nawrot et al (2017) suggest protein content of the Chelidonium can be affected by the biological activity of this taxa. They calm changes in the plant's needs at different developmental life stages from intense biosynthetic processes to defence against different environmental factors such as pathogens can affect latex composition. These changes in phytochemical composition could explain the biological activity alteration and subsequently divergent medicinal use of the plant extracts in the different developmental stages. The skin treatment properties of C. majus might be related to antibacterial, antifungal, antiviral and anti-inflammation activities of these taxa. It seems that these activities are attributed mostly to the alkaloids and flavonoids present in Chelidonium (Zuo et al., 2008; Zeileska et al. 2018). Stickl (1928) proved that the bactericidal properties are related to chelerythrine (Taborska Bochorakova, Dostal \& Paulova, 1995) and sanguinarine (Hadaruga \& Hadaruga, 2009). Also, the glycosaminoglycan present in the latex beside alkaloids containing chelidonine (Monavari, Shahrabadi, Keyvani, Bokharaei-Salim, 2012), chelerythrine (Taborska, Bochorakova, Dostal \& Paulova, 1995), sanguinarine (Hadaruga \& Hadaruga, 2009), coptisine (Bodalski, Pelezarskaund \& Ujec, 1958) and berberine is able to inhibit the development of human immunodeficiency virus (HIV)(Gerencer et al., 2006) and human papilloma virus (HPV) (Etxenagusia et al., 2000). The antifungal activity of Chelidonium is attributed to alkaloidal compounds such as dihydrochelerythrine and dihydrosanguinarine which inhibit spore germination and the growth of mycelium in fungi (Maji \& Pratim, 2015).

The other most reported indications of C. majus, both in European/Mediterranean and East Asian (TCM) traditions were for various liver complaints (Zielinska et al., 2018). Some of the hepatoprotective and choleretic/cholagogue activities might be explained by the presence of hydroxycinnamic (caffeic) acids' esters and dihydrochelerythrine (Weiskirchen, 2016). The in vivo research indicated that the phenolic components and alkaloids contain chelidonine, berberine and theprotopine showed choleretic activity and caused an increase in the bile acid flow. It seems this effect is responsible for their hepatoprotective activity (Vahlensieck et al., 1995).

The main concern in Chelidonium is a possible hepatotoxicity of the plant because of the presence of alkaloids (Maji \& Pratim, 2015; Zeileska et al. 2018). Research points out dosedependent toxicity and according to EMA the toxicity of using dried parts of Chelidonium in a normal dose is low but severe and irreversible hepatotoxicity can happen in a high dose or chronic uptake (EMA, 2010). Nevertheless, further investigation is needed to determine possible toxic effects in daily administration and term of use.

\section{CONCLUSION}

C. majus is most commonly used for the treatment of skin diseases and liver disorders in Turkey and other countries. Considering the toxicity of this species alongside its traditional uses and common commercial materials, detailed morphological and anatomical structures can provide a useful tool to avoid contamination of this taxon with other drugs. 
Our results indicated that the morphological characters such as leaf and flower shape, seed-specific morphology provided useful tools for the identification of this taxon from the other genera in the Papaveraceae family. Also, the presence of orange latex in all parts of the fresh materials or articulated laticifers with remaining latex content can be used as authentication diagnostic characters in powdered herbal drugs or broken plant materials. The other anatomical structures such as the stem and root cross-section, trichomes and stomata type share common structures across all taxa of the family and provided a limited opportunity to support the identification of this taxon.

Peer-review: Externally peer-reviewed.

Author Contributions: Conception/Design of Study- G.Z., N.Y.D., Z.C.A., I.I.T.C.; Data Acquisition- G.Z., N.Y.D.; Data Analysis/Interpretation- G.Z., N.Y.D.; Drafting Manuscript- G.Z.; Critical Revision of Manuscript- G.Z., N.Y.D., Z.C.A., I.I.T.Ç.; Final Approval and Accountability- G.Z., N.Y.D., Z.C.A., I.I.T.Ç.

Conflict of Interest: The authors have no conflict of interest to declare.

Financial Disclosure: Authors declared no financial support.

\section{REFERENCES}

- $\quad$ Akbulut, S., \& Ozkan, Z. C. (2014). Traditional Usage of Some Wild Plants in Trabzon Region (Turkey). Kastamonu Uni., Orman Fakültesi Dergisi, 14(1), 135-145.

- $\quad$ Aljuraisy, Y. H., Mahdi, N. K., \& Al-Darraji, M. N. J. (2012) Cytotoxic effect of Chelidonium majus on cancer cell. Al-Anbar Journal of Veterinary Sciences, 5(1), 85-90.

- $\quad$ Arı, S., Temel, M., Kargıoğlu, M., \& Konuk, M. (2015). Ethnobotanical survey of plants used in Afyonkarahisar-Turkey. Journal of Ethnobiology and Ethnomedicine, 11(84), 2015.

- Bellia, G., \& Pieroni, A. (2015). Isolated, but transnational: the local nature of Waldensian ethnobotany, Western Alps, NW Italy. Ethnobiology and Ethnomedicine, 11, 37.

- $\quad$ Benitez, G., Gonzalez-Tejero, M. R., \& Molero-Mesa, J. (2010). Pharmaceutical ethnobotany in the Western part of Granada province (Southern Spain): Ethnopharmacological synthesis Journal of Ethnopharmacology, 129, 87-105.

- Blanco, E., Macia, M. J., \& Morales, R. (1999). Medicinal and veterinary plants of El Caurel (Galicia, Northwest Spain). Journal of Ethnopharmacology, 65, 113-124.

- Bodalski, T., Pelezarskaund, H., \& Ujec, M. (1958). Action of some alkaloids of Chelidonium majus on Trichomonas vaginalis in vitro. Archivum Immunologiae et Therapiae Experimentalis, 6,705-711.

- Bussman R.W., Paniagua Zambrana, N.Y., Sikharulidze, S., Kikvidze, Z., Kikodze, D., Tchelidze, D.B.K., \& Robbie, E. (2017). Ethnobotany of Samtskhe-Javakheti, Sakartvelo (Republic of Georgia), Caucasus. Indian Journal of Traditional Knowledge, 16(1), 7-24.

- Calvo, M. I., Akerreta, S., \& Cavero, R.Y. (2011). Pharmaceutical ethnobotany in the Riverside of Navarra (Iberian Peninsula). Journal of Ethnopharmacology, 135, 22-23.

- Cavero, R.Y., Akerreta, S., \& Calvo, M. I. (2011). Pharmaceutical ethnobotany in the Middle Navarra (Iberian Peninsula). Journal of Ethnopharmacology, 137, 844-855.

- Cornara, L., La Rocca, A., Terrizzano, L., Dente, F., \& Mariotti, M.G. (2014). Ethnobotanical and phytomedical knowledge in the North-Western Ligurian Alps. Journal of Ethnopharmacology, 155(1), 463-484.
Cullen, J. (1965). Chelidonium. In: Davis PH (ed.) Flora of Turkey and the east Aegean Islands (vol.1, pp. 213-214). UK: Edinburgh University Press.

- $\quad$ Dei Cas, L., Pugni, F., \& Fico, G. (2015). Tradition of use on medicinal species in Valfurva (Sondrio, Italy). Journal of Ethnopharmacology, 163, 113-134.

- Dioscorides, P., Osbaldeston, T. A., \& Wood, R. P. A. (2000). Dioscorides de Materia Medica, Being a Herbal with Many other Materials Written in Greek in the First Century of the Common Era. An Indexed Version in Modern English. Johannesburg: Ibidis Press.

- $\quad$ European Medicines Agency (EMA). (2011, September 13) Committee on Herbal Medicinal Products (HMPC): Public statement on Chelidonium majus L., herba EMA/HMPC/743927/2010.Retrieved from https://www.ema.europa.eu/en/documents/public-statement/final-public-statement-chelidonium-majus-l-herba_en.pdf. Etxenagusia, M. A., Anda, M., Gonzalez-Mahave, I., Fernandez, E., \& Fernandez de Corres, L., (2000) Contact dermatitis from Chelidonium majus (greater celandine). Contact Dermat, 43, 47.

- $\quad$ Fortini, P., Di Marzio, P., Guarrera, P. M., \& lorizzi, M. (2016). Ethnobotanical study on the medicinal plants in the Mainarde Mountains (Central-Southern Apennine, Italy). Journal of Ethnopharmacology, 184, 208-218.

- Gaspar, N., Godinho, J., Vasconcelos, T., Caldas, D., Mendes, P., \& Barros, O. (2002). Ethnobotany in the center of portugal (Santarem) In: Rauter A.P., Palma F.B., Justino J., Araújo M.E., dos Santos S.P. (eds) Natural Products in the New Millennium: Prospects and Industrial Application. Proceedings of the Phytochemical Society of Europe, (vol. 47, pp.271-284) Springer, Dordrecht.

- Gerencer, M., Turecek, P. L., Kistner, O., Mitterer, A., Savidis- Dacho, H., \& Barrett, N.P. (2006) In vitro and in vivo anti-retroviral activity of the substance purified from the aqueous extract of Chelidonium majus L. Antiviral Research, 72(2),153-156.

Gilca, M., Gamana, L., Panaita, E., Stoian, I., \& Atanasiu, V. (2010). Chelidonium majus - an Integrative Review: Traditional Knowledge versus Modern Findings, Forsch Komplementmed, 17, 241-248.

Gonzalez-Hernandez, M. P., Romero, R., Rodriguez-Guitian, M., \& Rigueiro, A. (2004). Medicinal use of some plants in Galicia (NWSpain). Acta horticulture, 629, 63-75.

Görsöz, H. (2018). Türk Farmakopesi-2017. Ankara, Turkey: Artı 6 Reklam Matbaa.

- Grosso, C., Ferreres, F., Gil-Izquierdo, A., Valentão, P., Sampaio, M., Lima, J., \& Andrade, P. B. (2014). Box-Behnken factorial design to obtain a phenolic-rich extract from the aerial parts of Chelidonium majus L. Talanta, 130, 128-136. https://doi.org/10.1016/j. talanta.2014.06.043

- Guarrera, P. M., Forti, G., \& Marignoli, S. (2005). Ethnobotanical and ethnomedicinal uses of plants in the district of Acquapendente (Latium, Central Italy). Journal of Ethnopharmacology, 96, 429-444. Güner, A., Aslan, S., Ekim, T., Vural, M., \& Babaç, M.T. (Eds). (2012). Türkiye Bitkileri Listesi (Damarlı Bitkiler) (pp. 281-282). Istanbul, Turkey: N. Gökyiğit Botanik Bahçesi \& Flora Araştırmaları Derneği Yayınları.

- Hadaruga, D. I., \& Hadaruga, N. G. (2009) Antioxidant activity of Chelidonium majus L. extracts from the Banat county. Journal of Agroalimentary Processes and Technologies, 15(3), 396-402.

- Hao, D., Gu, X., \& Xiao, P. (2015) Medicinal Plants Chemistry, Biology and Omics (pp.171-216). UK: Woodhead Publishing.

Huang, C. K. (1999). The Pharmacology of Chinese Herbs ( $2^{\text {nd }}$ ed.). USA: CRC Press.

Idolo, M., Motti, R., \& Mazzoleni, S. (2009). Ethnobotanical and phytomedicinal knowledge in a long-history protected area, the Abruzzo, Lazio and Molise National Park (Italian Apennines). Journal of Ethnopharmacology, 127, 379-395. 
• Işcan, G., Köse, Y. B. \& Demirci, F. (2019) Bitkisel Drogların Makroskobik ve Mikroskobik Özellikleri (pp 88-89). Türkiye: Antalya Eczaci Odası Yayını No :1.

- Ivancheva, S. \& Statcheva, B. (2000). Ethnobotanical inventory of medicinal plants in Bulgaria. Journal of Ethnopharmacology, 69, 165-172.

- Jaric, S., Macukanovic-Jocic, M., Djurdjevic, L., Mijatovic, M., Kostic, O., Karadzic, B. \& Pavlovic, P. (2015). An ethnobotanical survey of traditionally used plants on Suva planner mountain (Southeastern Serbia). Journal of Ethnopharmacology, 175, 93-108.

- Jaric, S., Popovic, Z., Macukanovic-Jocic, M., Djurdjevic, L., Mijatovic, M., Karadzic, B. \& Pavlovic, P. (2007). An ethnobotanical study on the usage of wild medicinal herbs form Kopaonik Mountain (Central Serbia). Journal of Ethnopharmacology, 111, 160-175.

- Jones, W.H.S. (1966). Pliny Natural History with an English Translation in Ten Volumes, Vol. VII, Libri XXIV-XXVII. London: Harvard University Press.

- $\quad$ Kadereit, J.W. (1993). Papaveraceae. In: K. Kubitzki, J.G. Rohwer \& V. Bittrich (eds.) The families and genera of vascular plants (vol.2, pp. 494-506). Berlin: Springer-Verlag.

- Kedzia, B., Łozykowska, K. \& Gryszczynska, A. (2013). Chemical composition and contents of biological active substances in Chelidonium majus L. Postepy Fitoterapii, 3, 174-181.

- Kızılarslan, Ç. \& Özhatay, N. (2012). Wild Plants Used as Medicinal Purpose in the South Part of Izmit (Northwest Turkey), Turkish Journal of Pharmaceutical Science, 9(2), 199-218.

- Kokoska, L., Polensky, Z., Rada, V., Nepovim, A. \& Vanek, T. (2002) Screening of some Siberian medicinal plants for antimicrobial activity. Journal of Ethnopharmacology, 82(1), 51-53.

- Krahulcova A. (1982). Cytotaxonomic study of Chelidonium majus L. s. I. Folia Geobotanica et Phytotaxonomica, 17, 237-268.

- Kültür, Ş. (2007). Medicinal plants used in Kırklareli Province (Turkey). Journal of Ethnopharmacology, 111, 341-364.

- Lee, Y.C., Kim, S.H., Roh, S.S., Choi, H.Y. \& Seo, Y.B. (2007) Suppressive effects of Chelidonium majus methanol extract in knee joint, regional lymph nodes, and spleen on collagen-induced arthritis in mice. Journal of Ethnopharmacology, 112(1), 40-48.

- Leporatti, M.L. \& Ivancheva, S. (2003). Preliminary comparative analysis of medicinal plants used in the traditional medicine of Bulgaria and Italy. Journal of Ethnopharmacology, 87, 123-142.

- Linnaeus, C. (1753) Chelidonium, Species Plantarum, vol. 1. (pp.505). Stockholmiae

- Lumpert, M. \& Kreft, S. (2017). Folk use of medicinal plants in Karst and Gorjanci, Slovenia. Journal of Ethnobiology and Ethnomedicine, 13,16.

- Maji, A., K. \& Pratim, B. (2015). Chelidonium majus L. (Greater celandine) - A Review on its Phytochemical and Therapeutic Perspectives. International Journal of Herbal Medicine, 3(1), 10-27. https:// doi.org/10.22271/flora.2015.v3.11.03.

- Mayer, J. G., Uehleke, B. \& Saum, K. (2003). Handbuch der Klosterheilkunde (pp.213-221). Muenchen: Verlag Zabert Sandmann.

- Menale, B., Amato, G., Di Prisco, C. \& Muoio, R. (2006). Traditional uses of plants in North-Western Molise (Central Italy). Delpinoa, 48, 29-36.

- Menendez-baceta, G., Aceituno-mata, L., Molina, M., Reyes-garcia, V., Tardio, J. \& Pardo-de-santayana, M. (2014). Medicinal plants traditionally used in the Northwest of the Basque Country (Biscay and Alava), Iberian Peninsula. Journal of Ethnopharmacology, 152, 113-134.

- Menkovic, N., Savikin, K., Tasic, S., Zdunic, G., Stesevic, D., Milosavljevic, S. \& Vincek, D. (2011). Ethnobotanical study on traditional uses of wild medicinal plant in Prokletije Mountains (Montenegro). Journal of Ethnopharmacology, 133, 97-107.
Metcalfe, C.R. \& Chalk, L. (1957). Anatomy of the Dicotyledons (vol. 1., pp.74-78). London: Oxford Univ. Press. https://doi. org/10.1111/j.2042-7158.1950.tb13008.x

Miraldi, E., Ferri, S. \& Mostaghimi, V. (2001). Botanical drugs and preparations in the traditional medicine of West Azerbaijan (Iran) Journal of Ethnopharmacology, 75, 77-87.

- Monavari, S.H., Shahrabadi, M.S., Keyvani, H., Bokharaei- Salim, F. (2012) Evaluation of in vitro antiviral activity of Chelidonium majus L. against Herpes simplex virus type-1. African Journal of Microbiology Research, 6(20), 4360-4364.

Mumcu, Ü. \& Korkmaz, H. (2018) Ethnobotanical uses of alien and native plant species of Yeşilırmak Delta, Samsun, Turkey, Acta Biologica Turcica, 31(3), 102-113.

Mustafa, B., Hajdari, A., Krasniqi, F., Hoxha, E., Ademi, H., Quave, C.L., Pieroni, A. (2012). Medical ethnobotany of the Albanian Alps in Kosovo. Journal of Ethnobiology and Ethnomedicine, 8:6.

Mustafa, B., Hajdari, A., Pajazita, Q., Syla, B., Quave, C.L. \& Pieroni, A. (2012). An ethnobotanical survey of the Gollak region, Kosovo. Genetic Resources and Crop Evolution, 59, 739-754.

- $\quad$ Nawrot, R., Jozefiak, D., Sip, A., Kuzma, D., Musidlak, O., GozdzickaJózefiak, A. (2017). Isolation and characterization of a non-specific lipid transfer protein from Chelidonium majus L. latex. International Journal of Biological Macromolecules, 104(Pt A), 554-563. https://doi.org/10.1016/j.jjbiomac.2017.06.057

- $\quad$ Neves, J.M., Matos, C., Moutinho, C., Queiroz, G. \& Gomes, L.R. (2009). Ethnopharmacological notes about ancient uses of medicinal plants in Tras-os-Montes (Northern of Portugal) Journal of Ethnopharmacology, 124, 270-283.

- Novais, M.H., Santos, I., Mendes, S. \& Pinto-Gomes, C. (2004). Studies on pharmaceutical ethnobotany in Arrabida Natural Park (Portugal) Journal of Ethnopharmacology, 93, 183-195.

Pallag, A., Pasca, B., Taichiș, D. I., Honiges, A., Moisa, C., (2015) Microscopic studies of some Chelidonium majus L. populations. Analele Universităţii din Oradea, Fascicula: Ecotoxicologie, Zootehnie şi Tehnologii de Industrie Alimntară, 14B, 391-396.

Pantano, F., Mannocchi, G., Marinelli, E., Gentili, S., Graziano, S., Busardò, F.P. \& Di Luca, N.M. (2017). Hepatotoxicity induced by greater celandine (Chelidonium majus L.): a review of the literature. European Review for Medical and Pharmacological Sciences, 21(1), 46-52.

Papp, N., Birkas-Frendl, K., Farkas, A. \& Pieroni, A. (2013). An ethnobotanical study on home gardens in a Transylvanian Hungarian Csango village (Romania). Genetic Resources and Crop Evolution, 60, 1423-1432.

- $\quad$ Passalacqua, N.G., Guarrera, P.M. \& De Fine, G. (2007). Contribution to the knowledge of the folk plant medicine in Calabria region (Southern Italy). Fitoterapia, 78, 52-68.

- $\quad$ Pieroni, A., Dibra, B., Grishaj, G., Grishaj, I. \& Maçai, S.G. (2005). Traditional phytotherapy of the Albanians of Lepushe, Northenr Albanian Alps. Fitoterapia, 76, 379-399.

- Pieroni, A., Ibraliu, A., Abbasi, A.M. \& Papajani-Toska, V. (2015). An ethnobotanical study among Albanians and Armenians living in the Rraice and Mokra area of Eastern Albania. Genetic Resources and Crop Evolution, 62, 477-500.

Polat, R., Cakilcioglu, U., Kaltalioğlu, K., Ulusan, M.D. \& Türkmen, Z. (2015). An ethnobotanical study on medicinal plants in Espiye and its surrounding (Giresun-Turkey). Journal of Ethnopharmacology, 163, 1-11.

Prieroni, A., Giusti, M.E., Münz, H., Lenzarini, C., Turkovic, G. \& Turkovic, A. (2003). Ethnobotanical knowledge of the Istro-Romanians of Zejane in Croatia. Fitoterapia, 74, 710-719.

Redzic, S.S. (2007). The ecological aspect of ethnobotany and ethnopharmacology of population in Bosnia and Herzegovina. Collegium Antropologicum, 31(3), 869-890. 
- Rigat, M., Valles, J., D’Ambrosio, U., Gras, A., Iglesias, J. \& Garnatje, T. (2015). Plants with topical uses in the Ripples district (Pyrenees, Catalonia, Iberian Peninsula): Ethnobotanical survey and pharmacological validation in the literature. Journal of Ethnopharmacology, 164, 162-179.

- $\quad$ Saraç, D.U., Ozkan, Z.C. \& Akbulut, S. (2013). Ethnobotanic features of Rize/Turkey province. Biological Diversity and Conservation, 6(3), 57-66.

- Sargin, S.A., Selvi, S. \& Lopez, V. (2015). Ethnomedicinal plants of Sarigöl district (Manisa), Turkey. Journal of Ethnopharmacology, 171, 64-84.

- $\quad$ Sargın, S.A., Akçicek, E. \& Selvi, S. (2013). An ethnobotanical study of medicinal plants used by the local people of Alaşehir (Manisa) in Turkey. Journal of Ethnopharmacology, 150(3), 860-874.

- Saric-Kundalic, B., Dobes, C., Klatte-Asselmeyer, V. \& Saukel, J. (2010). Ethnobotanical study on medicinal use of wild and cultivated plants in middle, South and West Bosnia and Herzegovina. Journal of Ethnopharmacology, 131, 33-55.

- $\quad$ Saric-Kundalic, B., Dobes, C., Klatte-Asselmeyer \& V. \& Saukel, J. (2011). Ethnobotanical survey of traditionally used plants in human therapy of east, North and Northeast Bosnia and Herzegovina. Journal of Ethnopharmacology, 133, 1051-1076.

- Savic, J., Macukanovic-Jocic, M. \& Jaric, S. (2019). Medical ethnobotany on the Javor Mountain (Bosnia and Herzegovina). European Journal of Integrative Medicine, 27, 52-64.

- Savikin, K., Zdunic, G., Menkovic, N., Zivkovic, J., Cujic, N., Terescenko, M. \& Bigovic, D. (2013). Ethnobotanical study on traditional use of medicinal plants in South-Western Serbia, Zlatibor district. Journal of Ethnopharmacology, 146, 803-810.

- Soukand, R. \& Pieroni, A. (2016). The importance of a border: Medical, veterinary, and wild food ethnobotany of the Hutsuls living on the Romanian and Ukrainian sides of Bukovina. Journal of Ethnopharmacology, 185, 17-40.

- $\quad$ Stickl, O. (1928) Die bactericide Wirkung der Extrakte und Alkaloide des Schöllkrautes (Chelidonium majus) auf gram positive. Pathogene Mikroorganismen. Zeitschrift für Hygiene und Infektionskrankheiten, 108, 567-577. https://doi.org/10.1007/BF02201625
Taborska, E., Bochorakova, H., Dostal, J. \& Paulova, H. (1995) The greater celandine (Chelidonium majus L.) - review of present knowledge. Ceska a Slovenska Farmacie, 144(2), 71-75.

Ünsal, Ç., Vural, H., Sarıyar, G., Özbek, B. \& Ötük, G. (2010) Traditional Medicine in Bilecik Province (Turkey) and Antimicrobial Activities of Selected Species. Turkish Journal of Pharmaceutical Science, 7(2), 139-150.

- Uzun, E., Sarıyar, G., Adsersen, A., Karakoc, B., Ötük, G., Oktayoğlu, E. \& Pirildar, S. (2004) Traditional medicine in Sakarya province (Turkey) and antimicrobial activities of selected species. Journal of Ethnopharmacology, 95, 287-296.

Vahlensieck, U., Hahn, R., Winterhoff, H., Gumbinger, H.G., Nahrstedt, A. \& Kemper, F.H. (1995) The effect of Chelidonium majus herb extract on choleresis in the isolated perfused rat liver. Planta Medica, 61(3), 267-271.

- Varga F., Solic, I., Dujakovic, M.J., Luczaj, L.\& Grdisa, M., (2019) The first contribution to the ethnobotany of inland Dalmatia: medicinal and wild food plants of the Knin area, Croatia. Acta Societatis Botanicorum Polonaise, 88(2), 3622.

- Weiskirchen, R., (2016) Hepatoprotective and anti-fibrotic agents: it's time to take the next step. Frontiers in Pharmacology, 6(303), 1-40. https://doi.org/10.3389/ fphar.2015.00303

- World Health Organization. (2010) WHO Monographs on medicinal plants commonly used in the Newly Independent States (NIS) (pp.73-91). Geneva:WHO Press.

- Zielinska, S., Jezierska-Domaradzka, A., Wójciak-Kosior, M., Sowa, I., Junka, A. \& Matkowski, A.M. (2018). Greater Celandine's Ups and Downs-21 Centuries of Medicinal Uses of Chelidonium majus From the Viewpoint of Today's. Pharmacology. Frontiers Pharmacology, 9, 299. https://doi.org/10.3389/fphar.2018.00299

- Zuo, G.Y., Meng, F.Y., Hao, X.Y., Zhang, Y.L., Wang, G.C. \& Xu, G.L. (2008) Antibacterial alkaloids from Chelidonium majus Linn (Papaveraceae) against clinical isolated of methicillin resistant Staphylococcus aureus. Journal of Pharmacy and Pharmaceutical Science, 11(4), 90-94. https://doi.org/10.18433/J3D30Q 